\title{
Notícia: V Congresso Nacional da Psicologia: Protagonismo Social da Psicologia
}

\author{
Marcus Adams de A. Pinheiro ${ }^{1}$ \\ Conselho Federal de Psicologia
}

\section{News: V National Congress of Psychology: Social Protagonism in Psychology}

O Conselho Federal de Psicologia juntamente com o sistema Conselhos promovem o V Congresso da Psicologia (V CNP), em Brasília, de 17 a 20 de junho de 2004. O evento tem como objetivo construir um programa de participação efetiva da Psicologia na transformação da sociedade brasileira, ampliando a inserção social e a possibilidade de formular respostas para as necessidades sociais urgentes do Brasil.

O Congresso Nacional é um projeto amplo de debates que se inicia nas bases, próximo aos psicólogos, isto é, em suas cidades e seus respectivos Conselhos Regionais, subsedes ou seções. A partir do desenvolvimento das discussões, alguns representantes, chamados delegados, se encarregam de encaminhar proposições reunindo-se com os outros representantes. No que concerne os Direitos Humanos, os Conselhos Regionais têm como objetivos: a) a inserção da Psicologia nas questões relativas aos povos indígenas brasileiros, contribuindo para o fortalecimento das diversas etnias e trabalhando na defesa dos direitos humanos e civis; b) a ampliação da inserção da categoria em fóruns de controle social e movimentos sociais, buscando transformar e qualificar a prática profissional, através da troca com outros saberes; c) aprofundar o debate dos aspectos éticos e do compromisso social da Psicologia nas organizações, no sentido de interferir nos processos de exclusão segmentada (negros, idosos, mulheres, portadores de deficiência, homossexuais dentre outras categorias); d) que os métodos psicológicos não sejam utilizados para reforçar preconceitos e estereótipos contra grupos minoritários; e) vínculo com a luta contra o rebaixamento da idade penal, pela total implementação do Estatuto da Criança e do Adolescente e priorização de políticas públicas na área da infância e adolescência visando contribuir para a transformação da sociedade. Em suma, enfatiza-se a necessidade de que a Psicologia exerça um trabalho qualificado e ético, lutando pela transformação da sociedade brasileira, construindo melhores condições de vida e buscando um mundo melhor para todos, visto que são muitas as urgências e as necessidades sociais.

O Congresso Nacional da Psicologia é uma conquista democrática da categoria, que foi instalado a partir do Processo Constituinte da Psicologia, ocorrido em 1994, possibilitando a transformação do papel, do funcionamento e da ação dos Conselhos de Psicologia em prol de uma sociedade democrática. Instância máxima de deliberação na estrutura dos

1 Endereço: SRTVN 702 Ed. Brasília Rádio Center, Sala 4024 A, Brasília, DF, Brasil 70719-900. E-mail: marcusadams@yahoo.com.br
Conselhos, de três em três anos, aprova as diretrizes básicas para a ação dos Conselhos de Psicologia. Os CNPs também se constituem como o momento em que são inscritas chapas que concorrem às eleições para a direção da autarquia. Cada congresso tem um tema aprovado e discutido amplamente pela Assembléia de Políticas Administrativas e Financeiras (APAF).

Então, a mobilização dos psicólogos do país para o desenvolvimento da Psicologia, como ciência e profissão, vem se organizando ao longo dos quatro eventos já realizados. A saber:

- I Congresso Nacional Constituinte da Psicologia (Campos do Jordão, 1994)

Tema: Processo Constituinte Repensando a Psicologia.

- II Congresso Nacional da Psicologia (Belo Horizonte, 1996)

Tema: Formação, Exercício Profissional e as Leis 4.119 e 5.766.

- III Congresso Nacional da Psicologia (Florianópolis, 1998)

Tema: Psicologia: Interfaces, Políticas Públicas e Globalização.

- IV Congresso Nacional da Psicologia (Brasília, 2001) Tema: Qualidade, Ética e Cidadania nos Serviços Profissionais: Construindo o Compromisso Social da Psicologia. Em junho próximo, o V CNP terá como tema "Protagonismo Social da Psicologia: As Urgências Brasileiras e a Construção de Respostas da Psicologia às Necessidades Sociais". O convite é para pensar o futuro da profissão e da ciência, a partir do trabalho cotidiano de cada um. A meta principal do encontro é construir o programa desta empreitada, cujos eixos de discussão propostos são:

- Políticas Públicas

- Inclusão Social e Direitos Humanos

- Exercício Profissional Para tanto, quatro etapas foram previstas:

- Eventos preparatórios: realizados em diversas localidades, entre setembro de 2003 e março de 2004, tinham como objetivo suscitar debates e levantar questões para a formulação de teses.

- Pré-congressos: nessa etapa, cujo encerramento está previsto para 18 de abril de 2004, os delegados são eleitos e as teses desenvolvidas no âmbito regional são apreciadas e aprovadas.

- Congresso Regional: composto por delegados eleitos nos pré-congressos, será realizado em cada Conselho Regional até 16 de maio de 2004, visando a apreciação das 
teses nacionais e a eleição dos delegados que integrarão o Congresso Nacional.

- Congresso Nacional: previsto para 17 a 20 de junho de 2004, em Brasília, constitui a etapa final do processo de discussão e decisão sobre as orientações para a atuação dos Conselhos de Psicologia.
Em todos os estados, os conselhos regionais já estão se preparando.

Participe! Procure o seu CRP e verifique a data do próximo compromisso!

Recebido em 23.03.2004

Primeira decisão editorial em 25.03.2004

Versão final em 30.03.2004

Aceito em 01.04.2004 